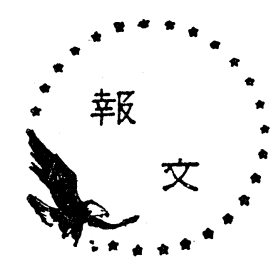

U. D.C. $662.753: 621.43 .019$

\section{自動車用ガソリンのオクタン価推定 \\ 一昭和 38 年 5 月 11 日受理一}

\section{I . 緒 論}

ガソリンのアンチノック性はガソリンのもつ種々な 性質によつて大い影響される。すなわち，炭化水素 成分の組成, 成分の複雑かつ不規則な組合せの結果 および, 添加剂による添加効果などが総合して表われ てくる。ゆえに, ガソリンの若干の物理的あるいは化 学的性質から, 試験エンジンによる特定な条件下にお ける実測值と同一結果を推定することは非常に困難な ことである。一方, オクタン価の決定にはに JIS K 2280 規定されているリサーチ法オクタン価測定試験 方法によつて求めるが, これには高額な試験設備と維 持費, 高度の技術, さらに貴重な時間と労力とを要す るのが現状である。

ここで筆者は, 自動車用ガソリンのもつ他の性状一 比重 $\left(15 / 4^{\circ} \mathrm{C}\right)$, 分留性状 $(10 \%$ および $90 \%$ 留出温度 $\left.{ }^{\circ} \mathrm{C}\right)$ およびアンチノック性向上のため添加される四エ チル鉛定量結果 $(\mathrm{ml} / \mathrm{gal})$ 一から実測オクタン価 (リ少 一千法）の概略值を比較的簡単にして迅速に推察する ための各種推定図表を作成した。

\section{II. 図表作成}

自動車用ガソリンの推定オクタン価を求めるため に, その各種性状中比重 $\left(15 / 4^{\circ} \mathrm{C}\right)$, 分留性状 $(10 \%$ お よび $90 \%$ 留出温度 $\left.{ }^{\circ} \mathrm{C}\right)$ および四エチル鉛量 $(\mathrm{m} l / \mathrm{gal})$ 分析結果から，おおよそつぎのようにして各種図表を 作成した。

1. 比重一分留平均温度一芳香族係数一沸点範囲係 数補正值の関係

幾多の実測結果をもとにし，またCox. の発表して いる結果1)を参考にしながら作図して Fig. 2〜 5 をつ くつた。すなわち，Cox. 法によればガソリンの沸点 範囲係数 F (Boiling Range Factor, ASTM 法) は次式で示されるが，これと分留平均温度 $\left(\frac{10 \%+90 \%}{2}{ }^{\circ} \mathrm{C}\right)$ との間には近似的に Fig.1 に示寸 ような関係があることを確めたので，推定操作に便利 なようにこの温度単位を Fig. 2〜 5 に用いた。

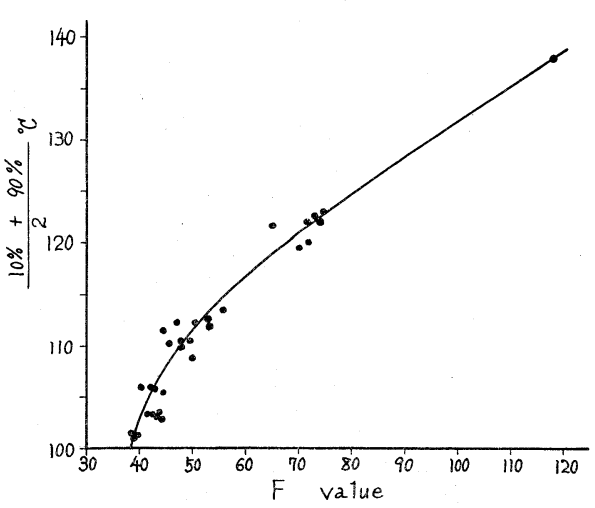

Fig. 1 Relation distillation range $\left(\frac{10 \%+90 \%}{2} \circ \mathrm{C}\right)$ to boiling

$$
\mathrm{F}=\left(\frac{10 \%^{\circ} \mathrm{F}}{100}\right)^{\left(1+\frac{10 \%{ }^{\circ} \mathrm{F}}{90 \%{ }^{\circ} \mathrm{F}}\right)} \times \frac{90 \%{ }^{\circ} \mathrm{F}}{10}
$$

また四エチル鉛添加による加鉛効果については Table 1 に示すように，一般に炭化水素成分，精製法 および含有イオウ分などによつて相当差違のあるもの であるが2，これらのものを市販の自動車用ガソリ ンについて, 比重, 分留平均温度抢よび芳香族係数 (Aromaticity Factor) におよぼす変化を, 実測結果を もとにし検討を加えた結果, 無添加, $1 \mathrm{~m} l / \mathrm{gal}, 2 \mathrm{~m} l$, $\mathrm{gal}, 3 \mathrm{ml} / \mathrm{gal}$ の各場合における関保をそれぞれ Fig. 2〜5にわけて図示した。

\section{2. 全補正值の決定}

ガソリンの分留試験には誤差が入りやすく, また含 有される不飽和炭化水素およびナフテン系, イソパラ フィン系炭化水素成分に対する補正の必要があり, Cox. 法に示されている 次式を参考にして, ガソリン の分留試験による $10 \%$ および $90 \%$ 留出温度 $\left({ }^{\circ} \mathrm{C}\right)$ と 比重とを組合せて求めた沸点範囲係数補正值 (Boiling Range Correction) B と, 前記留出温度とからFig. 6 により全補正值 $\mathrm{C}$ を求める。 
Table 1 Effect of TEL

\begin{tabular}{|c|c|c|c|c|c|c|c|c|c|}
\hline \multirow{2}{*}{ ガソリ } & \multirow{2}{*}{ ンンの種類 } & \multirow{2}{*}{$\begin{array}{c}\text { オクタン } \\
\text { 価 }\end{array}$} & \multicolumn{5}{|c|}{ オクタン価上䄯程度 $(\mathrm{ml} / \mathrm{gal})$} & \multirow{2}{*}{ 備 } & \multirow{2}{*}{ 考 } \\
\hline & & & 1 & 2 & 3 & 4 & 6 & & \\
\hline 直 留 & ガソリン & 54.5 & 14.9 & 21.3 & 25.2 & 27.9 & 31.8 & 接触脱流 & \\
\hline 天 然 & ガソリン & 61.6 & 13.6 & 19.6 & 23.1 & 25.5 & 28.9 & " & \\
\hline 直 留 & ガソリン & 43.4 & 10.7 & 16.9 & 21.1 & 24.0 & 28.2 & 低オクタン価, & イオウ分少 \\
\hline & $"$ & 55.9 & 9.7 & 14.6 & 17.7 & 19.8 & 22.9 & イオウ分少 & \\
\hline & $\prime \prime$ & 64.0 & 9.4 & 13.9 & 16.6 & 18.5 & 21.1 & 高オクタン価, & イオウ分少 \\
\hline & $\prime \prime$ & 71.6 & 8.0 & 11.8 & 13.8 & 15.3 & 17.4 & イオウ分少 & \\
\hline 天 然 & ガソリン & 65.7 & 8.4 & 12.4 & 14.8 & 16.8 & 18.8 & $" \prime$ & \\
\hline
\end{tabular}

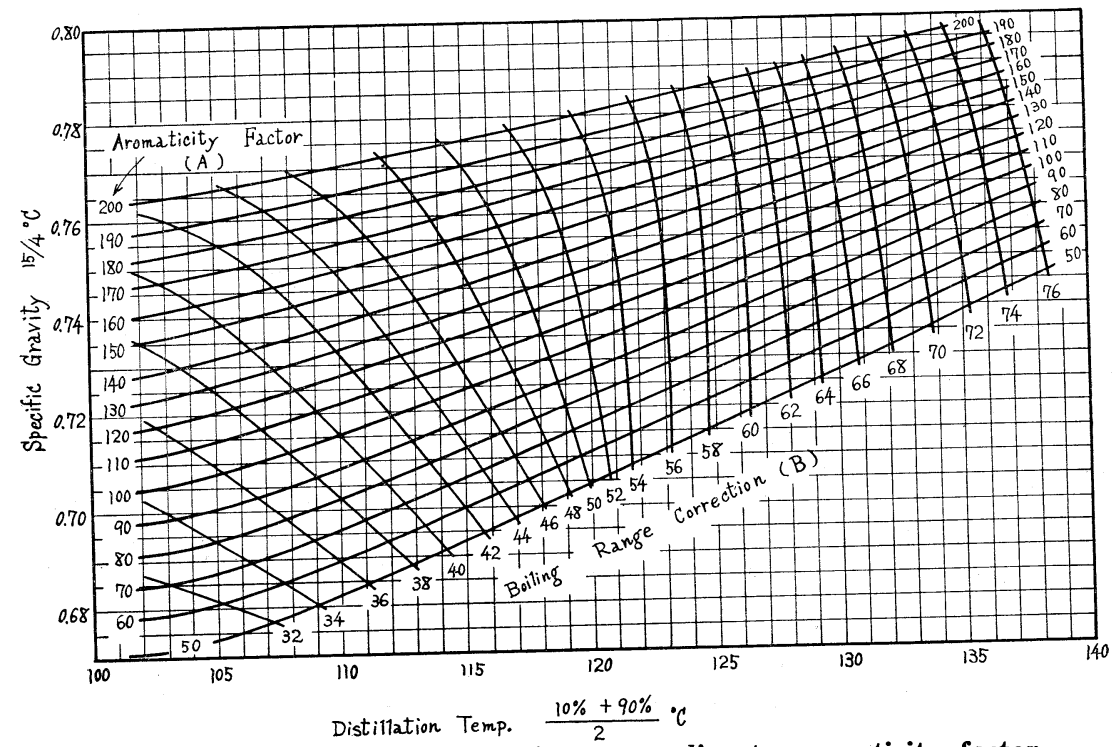

Fig. 2 Relation general properties of gasoline to aromaticity factor $A$ and boiling range correction $B$ (none additive)

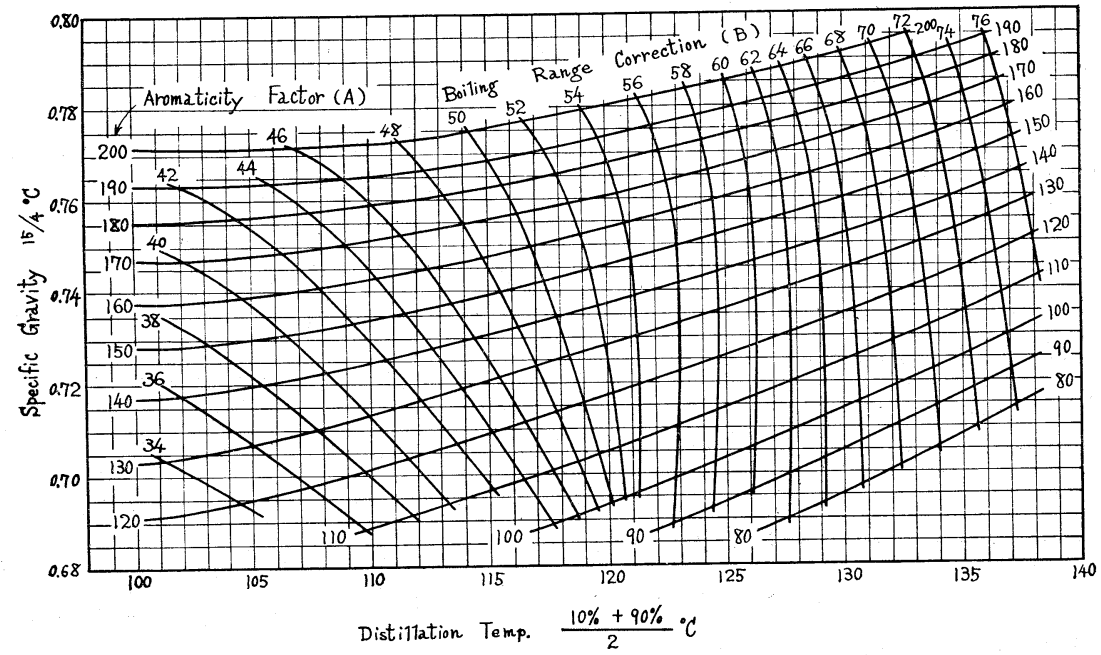

Fig. 3 Previous mention (TEL $1 \mathrm{ml} / \mathrm{gal}$ additive) 
additive to various gasoline

\begin{tabular}{|c|c|c|c|c|c|c|c|}
\hline \multirow{2}{*}{ ガソリンの種類 } & \multirow{2}{*}{$\begin{array}{c}\text { オクタン } \\
\text { 価 }\end{array}$} & \multicolumn{5}{|c|}{ オクタン価上昇程度 $(\mathrm{ml} / \mathrm{gal})$} & \multirow{2}{*}{ 備 } \\
\hline & & 1 & 2 & 3 & 4 & 6 & \\
\hline 直 留 ガソリン & 55.9 & 7.5 & 11.3 & 13.7 & 15.3 & 17.7 & イオウ分多 \\
\hline 分 解 ガソリン & 69.9 & 8.3 & 10.4 & 11.7 & 12.6 & 13.7 & 接触脱硫 \\
\hline 混 合 ガソリン & 83.0 & 8.1 & 11.6 & 14.1 & 16.2 & 18.4 & イソオクタン混合 \\
\hline 分 解 ガソリン & 57.5 & 8.1 & 12.2 & 14.7 & 16.5 & 18.9 & 低オクタン価 \\
\hline " & 64.5 & 6.5 & 9.5 & 11.3 & 12.6 & 14.4 & 普 通 \\
\hline " & 71.6 & 4.0 & 5.8 & 6.9 & 7.6 & 8.6 & 高オクタン価 \\
\hline 芳香族ガソリン & 72.6 & 6.2 & 9.0 & 10.6 & 11.6 & 13.2 & \\
\hline 分 解 ガソリン & 75.8 & 5.9 & 8.5 & 9.9 & 10.9 & 12.4 & フードリー接触 \\
\hline
\end{tabular}

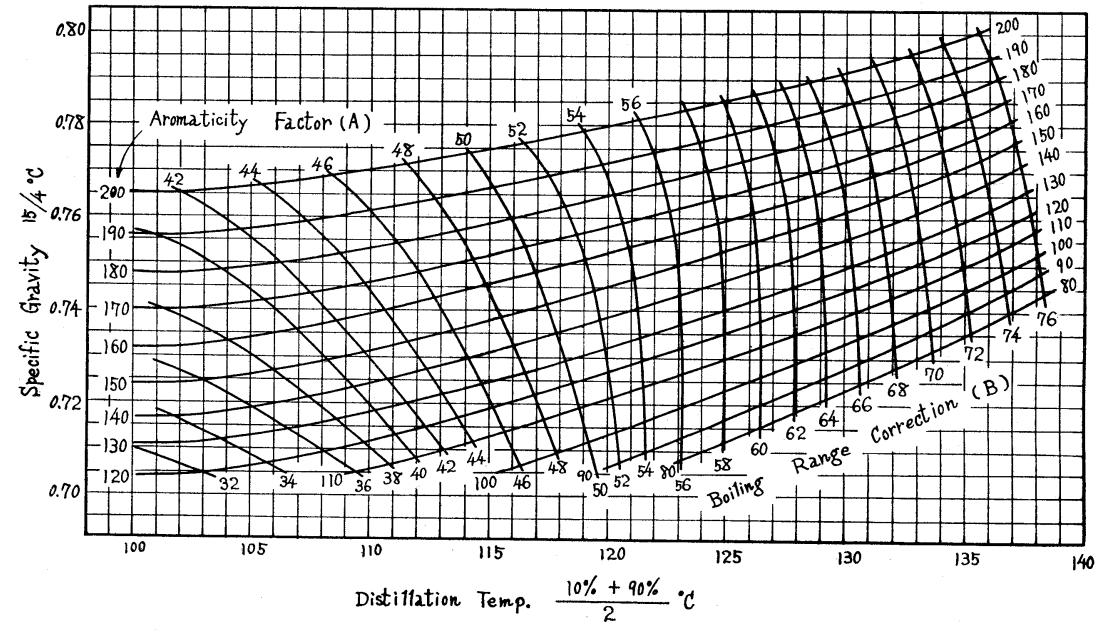

Fig. 4 Previous mention (TEL $2 \mathrm{ml} /$ gal additive)

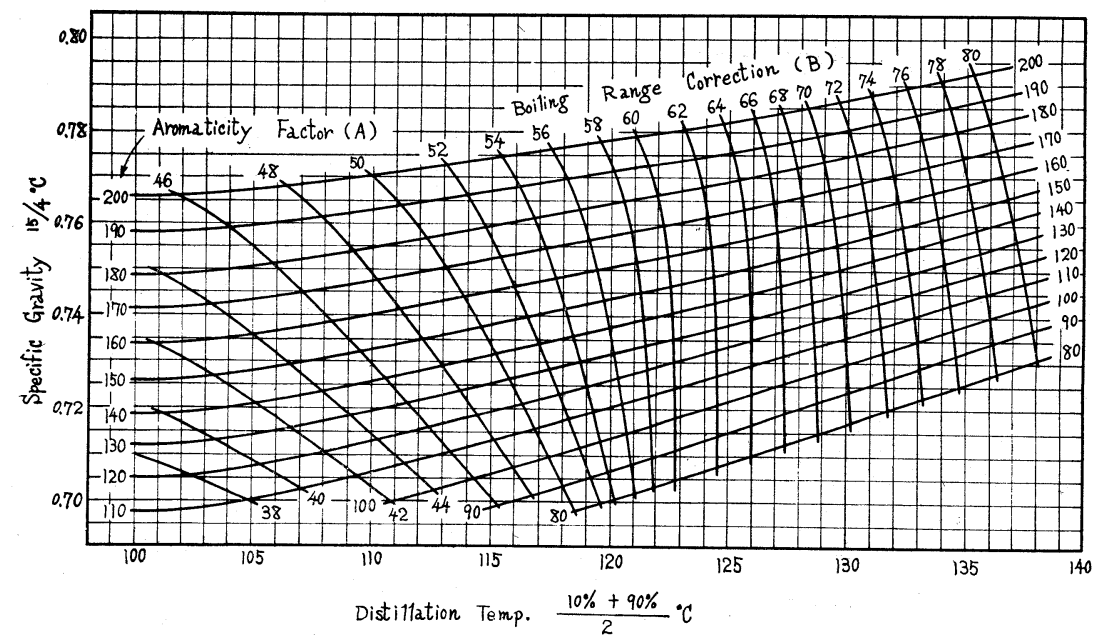

Fig. 5 Previous mention (TEL $3 \mathrm{ml} / \mathrm{gal}$ additive) 


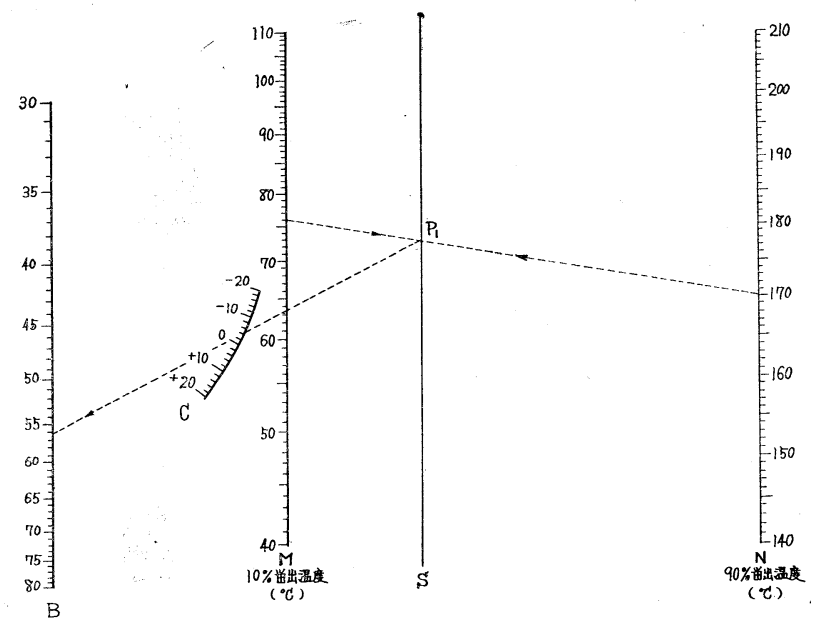

Fig. 6 Relation $10 \%$ \& $90 \%$ distillation temp. and boiling range correction $B$ to total correction C

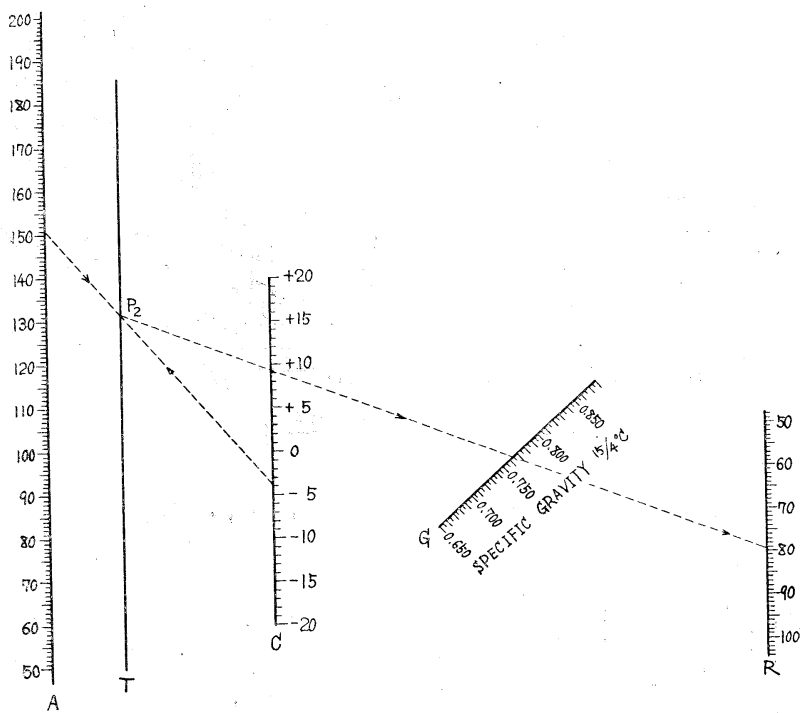

Fig. 7 Relation aromaticity factor $\mathrm{A}$, total correction $\mathrm{C}$ and specific gravity to assumed octane number

Cox. 法の全補正値推定

$$
\mathrm{C}=2\left(\mathrm{~B}-\frac{10 \%{ }^{\circ} \mathrm{F} \times 90 \%{ }^{\circ} \mathrm{F}}{1,000}\right)
$$

3. オクタン価の決定

Cox. 法に用いられている次式を参考にして，ガソ リンの比重, 芳香族係数㧍よび全補正值から推定オク タン価を求めるために Fig. 7 を作図した。

Cox. 法の

$$
\text { O. N. }=\frac{(\mathrm{A}+\mathrm{C}) \times(\text { API 比重 })}{100}
$$

A : 芳香族係数
$\mathrm{C}:$ 全補正值

III. 推定方法

本方法を使つて自動車用ガソリンのオクタン価（リ サーチ法によるオクタン価）を推定するには，㧍抒よ そつぎの順序で行なう。

1. 試料ガソリンの比重 $\left(15 / 4^{\circ} \mathrm{C}\right)$, 分留性状 $(10 \%$ お よび $90 \%$ 留出温度 $\left.{ }^{\circ} \mathrm{C}\right)$ および四エチル鉛添加量 $(\mathrm{m} l /$ gal）を測定する。

2. 四エチル鉛添加量測定結果から Fig. 2 5 のいず れを使うかを決定する。Fig. $2 \sim 5$ は $1 \mathrm{ml} / \mathrm{gal}$ 単位 
国凡些

䇉南入

曹要戈

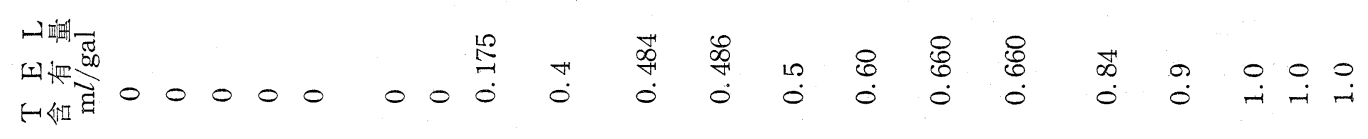

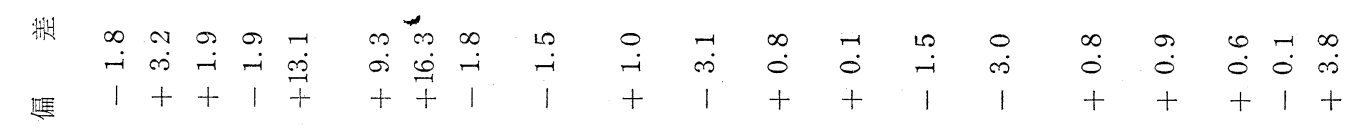

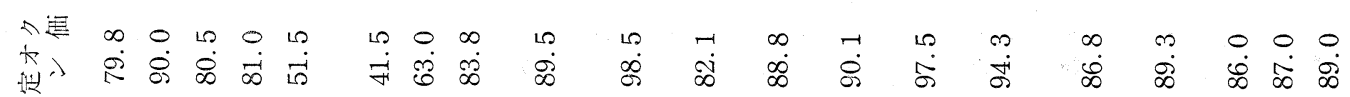
$+2$

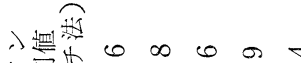

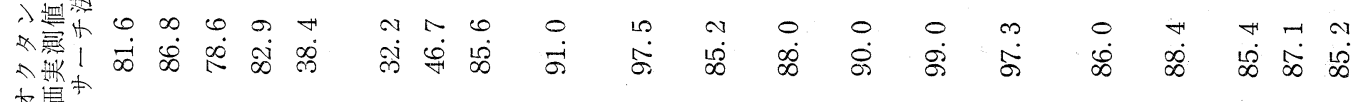
卡兵
地
$\begin{array}{cccc}1 & 1 & 1 & 1\end{array}$

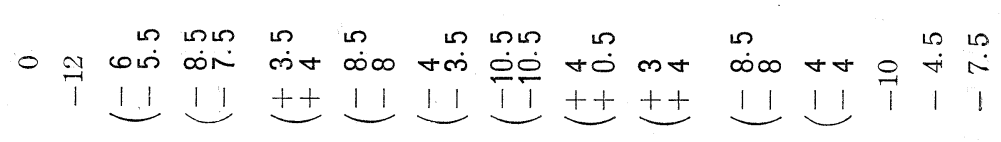

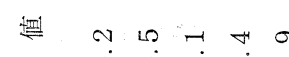

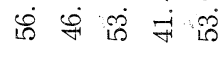
$\oplus$

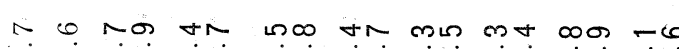
is
$0 \infty$ in $\infty$ is os

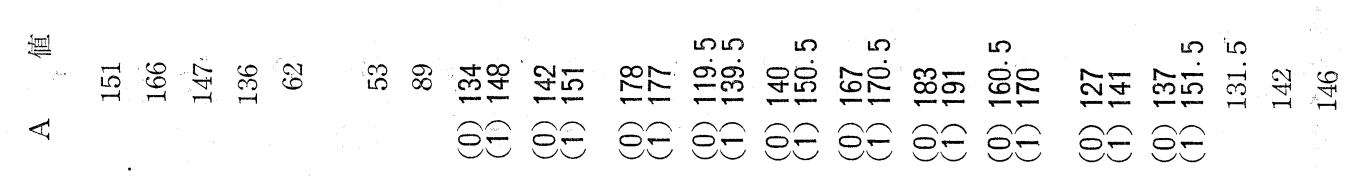

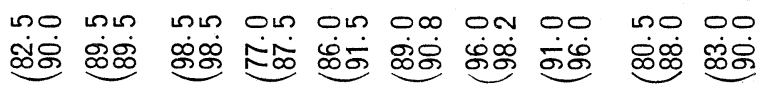

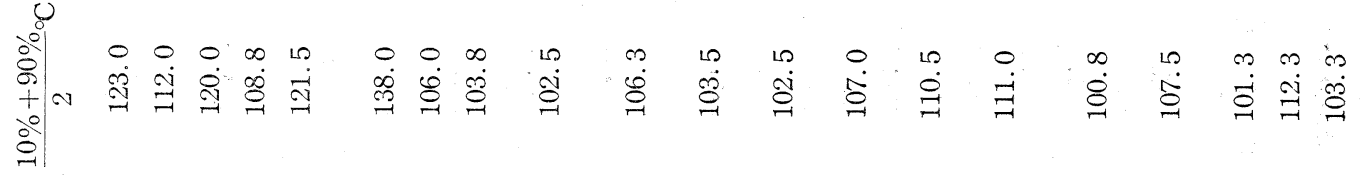

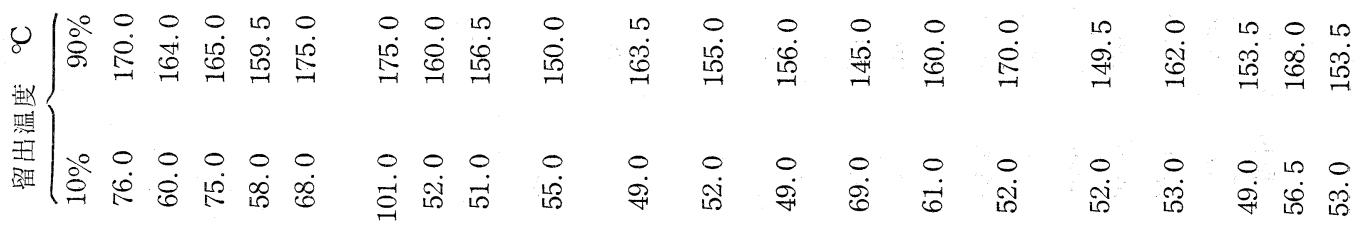

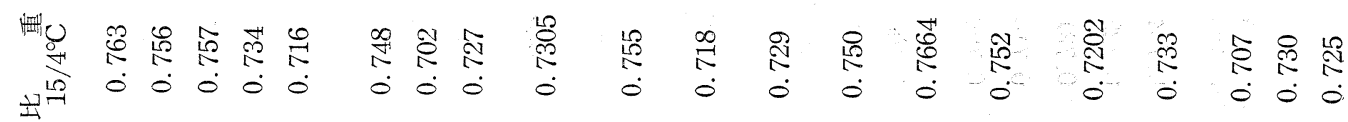

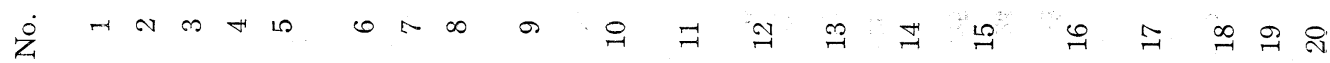


仺太遇

掫接入

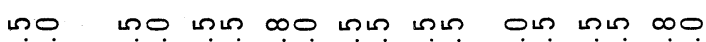

福带边

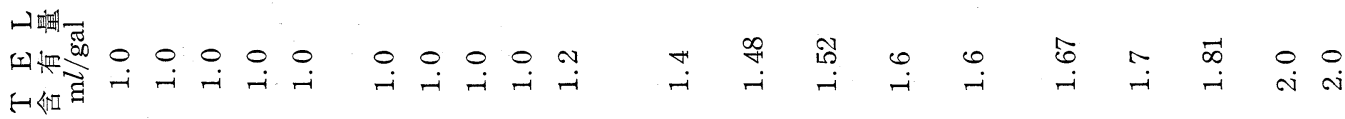
䊉

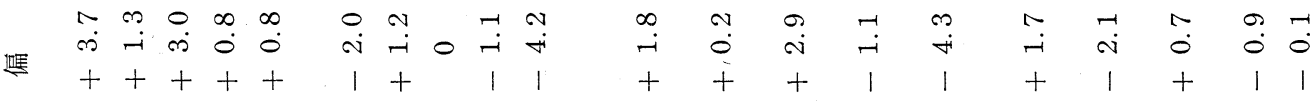
늘

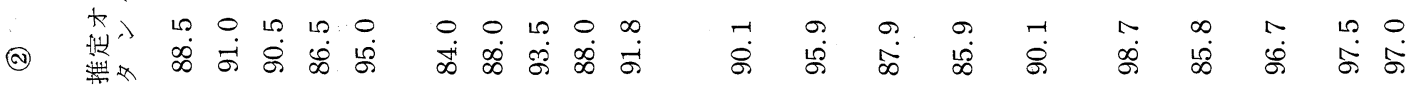

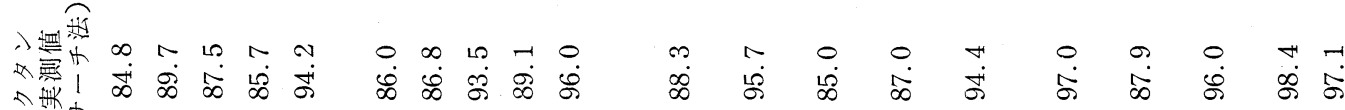
比些些

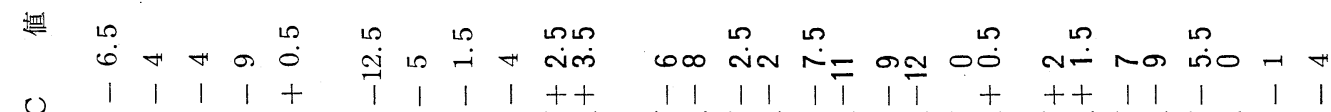

壃 की

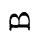

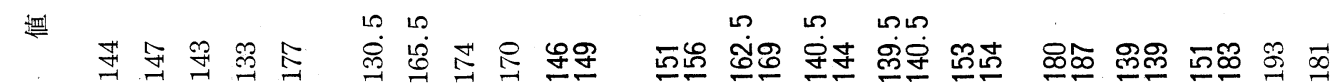

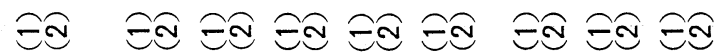

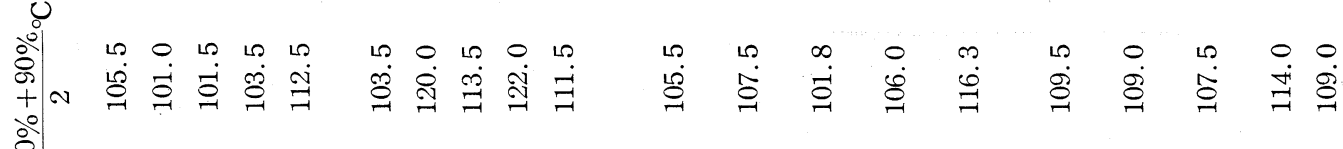

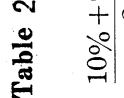

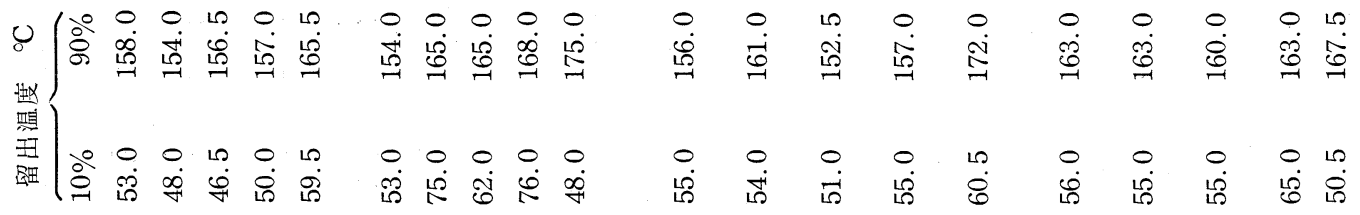

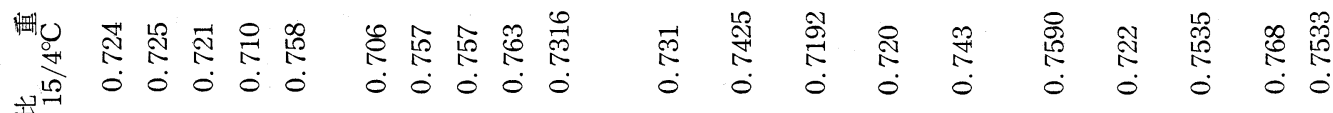

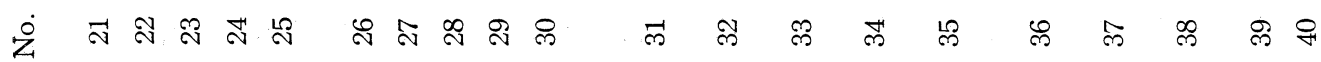


no no 00 nn nu nu nu

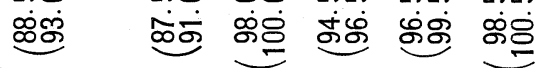

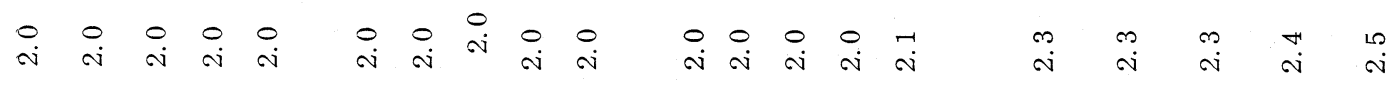

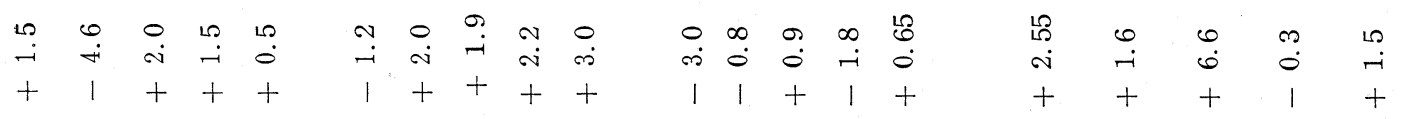

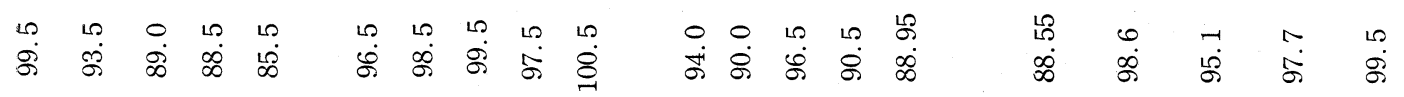

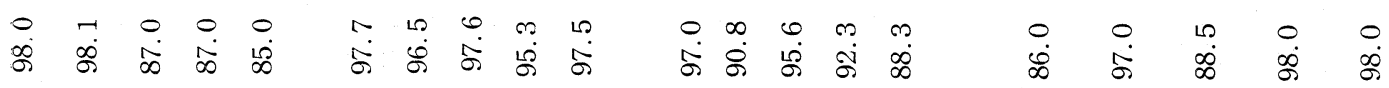

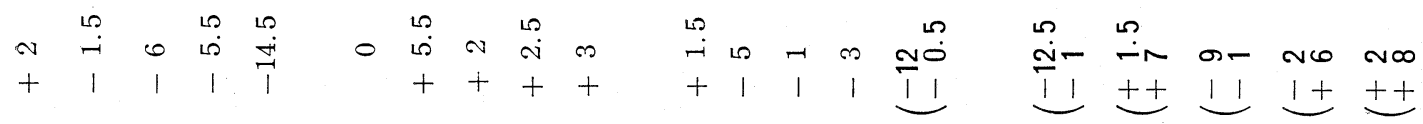

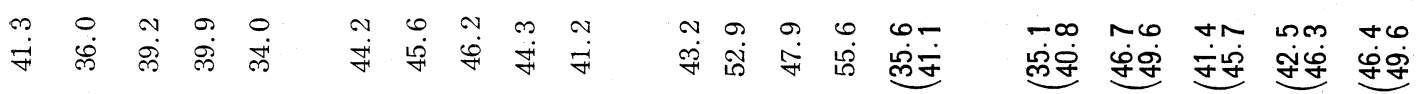

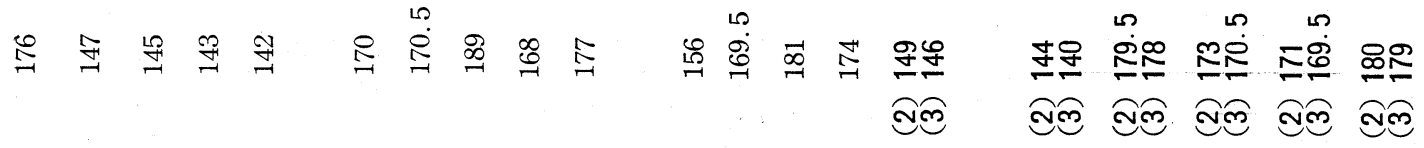

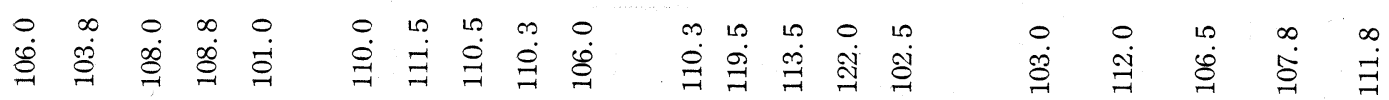

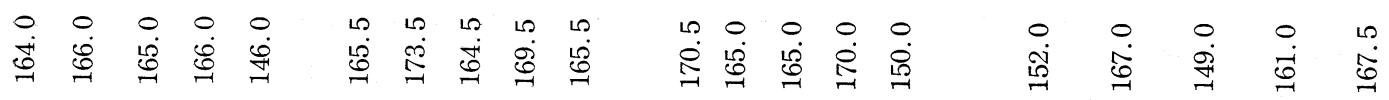

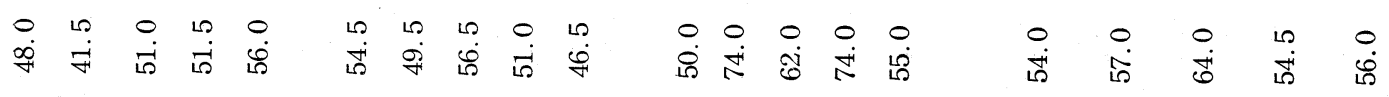

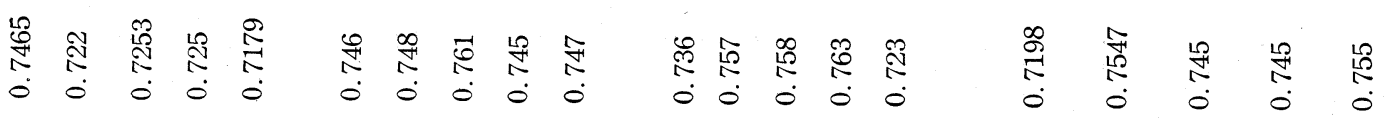

F 가교 \& 
五凡进

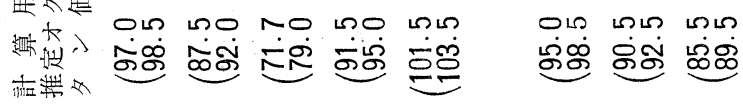

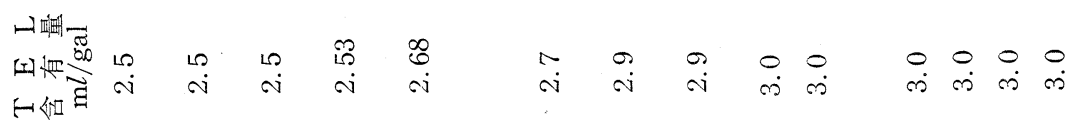

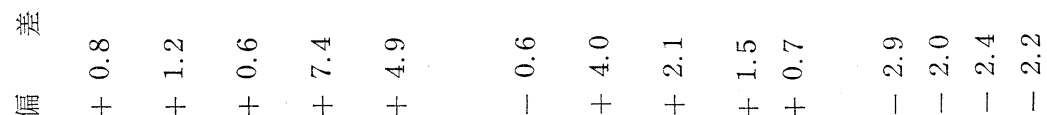

त进

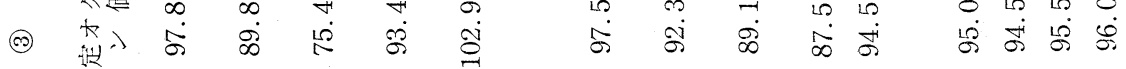

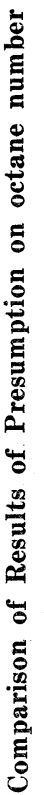

带处

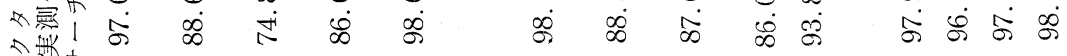
它界
還

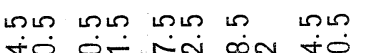

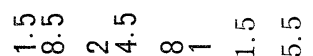

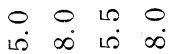

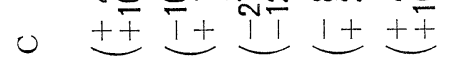
$1+\stackrel{1+}{1+}+$
$++++$
地 - on 00 no on
O- +m no $n$ m 0 H
प 近

$\infty$

噮

เกเก

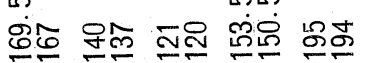

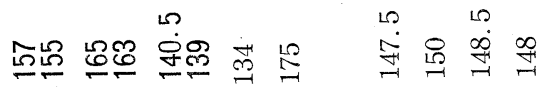

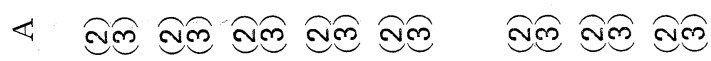

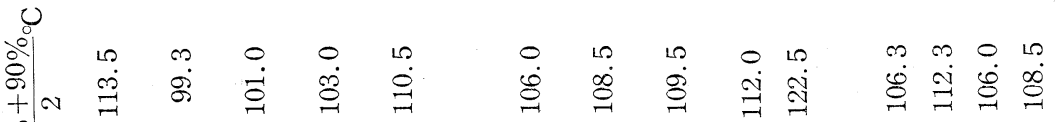

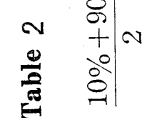

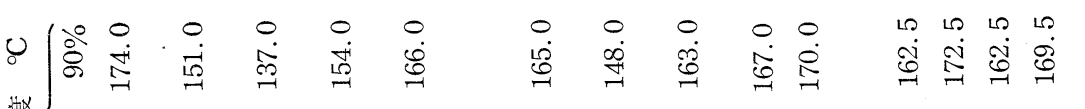

砵

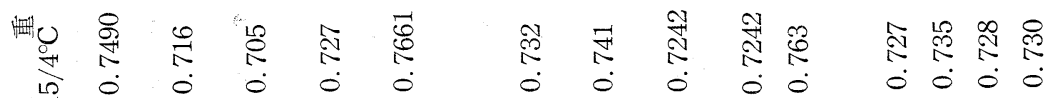


に区分してあるので，その中間值をとる場合はそれ をはさむ前後の 2 つ図面加らそれぞれ推定值を求 めてゆき, 最後に 2 つの推定オクタン価を比例換算 して近似值を求める。

3. Fig. 2〜5 を用い, 試料ガソリンの比重 $\left(15 / 4^{\circ} \mathrm{C}\right)$ と $\frac{10 \%+90 \%}{2}{ }^{\circ} \mathrm{C}$ とより交点を求め, 芳香族係数 $\mathrm{A}$ と沸点範囲係数補正值 $\mathrm{B}$ を読みとる。

4. Fig. 6 を用いて全補正值 Cを求める。すなわち, 試料ガソリンの $10 \%$ (M尺) および $90 \%$ （N尺） 各留出温度の測定值点を結んで $\mathrm{S}$ 尺上に交点 $\mathrm{P}_{1}$ を 求め, $\mathrm{P}_{1}$ と沸点範囲係数補正值 ( $\mathrm{B}$ 尺) の読取り目 盛とを結んでC尺との交点を読みとる。この読取り 值を全補正值とする。

5. Fig. 7 を用いて推定オクタン価を求める。すなお ち，(3）で読取つた芳香族係数をA尺上にとり，こ れと (4)で求めた全補正值をC尺にとつた点とを結 び，T尺との交点を $\mathrm{P}_{2}$ とする。ついで $\mathrm{P}_{2}$ と $\mathrm{G} 尺$ 上にとつた比重 $\left(15 / 4^{\circ} \mathrm{C}\right)$ 両者を結ぶ直線を延長し てR尺との交点を求める。この交点を R尺の目盛で 読取れば, この数值が推定オクタン価となる。

(例題) 今一例として Table 2 に示した最上欄のも のについてみると, 性状分析の 結果比重 $\left(15 / 4^{\circ} \mathrm{C}\right)$ が 0.763 , 分留性状は $10 \%, 90 \%$ 留出温度がそれ ぞれ $76.0^{\circ} \mathrm{C}$ および $170^{\circ} \mathrm{C}$ であり, TEL は無添加 であることが判明した。従つて

$$
\frac{10 \%+90 \%}{2}=123.0\left({ }^{\circ} \mathrm{C}\right)
$$

となり，芳香族係数などの推定には Fig. 2 を使う ことになる。Fig. 2 より芳香族係数 $=151$, 沸点範 囲係数補正值 $=56.2$ を読取る。Fig. 6 を用い (4) の要領 (Fig. 6 中に点線で示す) で全補正值 $\mathrm{C}=$ -4 を読取る。ついで Fig. 7 により（5）にのべた 要領 (Fig. 7 中に点線で示す) で推定オクタン価 79.8 を読取る。リサーチ法によるオクタン価実測 值は 81.6 であつたので, 実測值との偏差が -1.8 であることになる。

IV. 吟 味

各種市販自動車用ガツリンについて, オクタン価実 測值（リサーチ法）と本方法によるオクタン価推定值 とを比較してみると Table 2 のようになり,この結
果からリサーチ法によるオクタン価が 70 100 程度の 範囲内においては, 実測值との偏差が大半の場合 \pm 5 以下で一致することを確めた。しかし中には例外的に 7 程度の偏差を生ずるものがあり, ガソリンの比重, 沸点および TEL 量からでは推定することが困難と考 えられる品質のものも若干ではあるが存在する。また オクタン価が 50 以下程度の低オクタン・ガソリンに ついての推定結果を Table 2 No. 5〜7 に示したが, 結果として本方法による推定は低オクタン価のものに なるほど実測值との偏差が大きくなり，オクタン価50 付近以下では約 15 以上の偏差を生じる。JIS に規定 されているリサーチ法オクタン価測定試験方法では, 別人別装置による偏差許容量がオクタン価 75 以上程 度のものについては約1.1 オクタン価となつているの で, 本推定法による偏差はほとんどの場合その約 3 5 倍あることになり，これだけの偏差を許容できる場合 に限つてこの方法で推定できることになる。

\section{V. 結 論}

オクタン価の評価は自動車用ガソリンの各種性状中 最も重要な項目の一つであり, この值が不明では 1 号, 2 号の種別をつ汀ることは不可能に近い。ガソリ ン機関の圧縮比の上昇にともなつて高オクタン・ガソ リンを活用する傾向のきわめて強い今日, 正規の試験 エンジンによらなくとも, 比較的簡単に, 相当な精度 をもつてこれに代る推定法の確立こそ, 特に使用者側 にとつては非常に便利なことと考える。本方法はその 一方式として, ガソリンのもつ比重, 平均沸点, TEL 定量結果からオクタン価 (リサーチ法) を推定した が, オクタン価 70 以上のものについては, ごく一部 の例外を除いては 5.0 オクタン価以下の偏差をもつて 実測值と一致するものと考える。

最後に本研究を推進するにあたり, 多大の御支援を いただいた通産省鉱山局石油課, 日本石油横浜製油所 品質管理課および出光興産徳山製油所研究部各氏に対 し,心から厚くお礼申上げます。

\section{文献}

1) R. B. Cox, Refiner, 1940, 19, 31

2) 出光與産編, Petroleum Handbook, (1958)

3）舟阪渡, 燃料化学分析試験法 


\title{
Presumption on the Octane Number of Motor Gasoline
}

\author{
by Tsuyoshi Ogawa
}

(Maritime Safety Academy)

SYNOPSIS :-At present the anti-knocking property of motor gasoline is indicated by the octane number measured with the Research method of octane number measuring, but the author contrived the method of presumption on the amount of it simply with the knowledges on the general properties of motor gasoline the specific gravity $\left(15 / 4^{\circ} \mathrm{C}\right)$, distillation range $(10 \% \& 90 \%$ distillated temperatures) and the tetra ethyl lead content (ml/gal.).

Using these diagrames, it may be possible to calculate it simply and speedy with reasmahle considerable correctness.....max. error due to the presumption $5.0 \mathrm{O} . \mathrm{N}$. about more than seventy octane number.

\section{印度の石 炭 鉱 業}

中央鈗山研究所 (Central Mining Research Station) 所長 Sinha 博士によれば印度の石炭総埋蔵量 は深度 $1,200 \mathrm{~m}$ で 193 億 3,000 万 $\mathrm{t}$ と推定されている。石炭鉱業の重要さは 1963 年上期の石炭と亜炭が 鈗産物生産高の総価格の約 $70 \%$ を占めたことによって知ることができる。

石炭の生産は 2,3 の地域に集中しているので輸送の問題が生じている。産出は 4 州に限られ，その 5 ち Bihar と West Bengal は 1963 年上期の全生産高の約 $79 \%$ を示した。利用できる石炭の僅か 40 〜 50\%が回収されるのみで，このため回収率の增加をはかることが重要な研究課題となっている。この 点に関し Sinha 博士は露天堀石炭採堀公社の設立を提案している, また, 石炭生産高を 1980 年までに 3 億 5,000 万 $\mathrm{t} /$ 年 に達するよう計画しているので, 多くの炭鉱は深度が $1,220 \mathrm{~m}$ にるる゙ろらと述べて いる。インド石炭開発公社は最近 2,500 万/年の生産量が期待できる 14 深鈗の開発を提案した。そのう ち 9 炭鈗は Bihar により，ポーランドが援助し，3 炭鉣は英国の援助で Bokaroにあり，2 炭鉣は West Bengal にある。インド石炭開発公社の第 2 選炭プラントはポーランドと合弁で始められ，8,300 万ルピ 一以上かかるだろう。選炭された石炭は層状と塊状とが等量混合したものとなるだろら。

Mining J., Feb, 14 (1964) 